\title{
EVALUASI MASSA BATUAN TEROWONGAN EKSPLORASI URANIUM EKO-REMAJA, KALAN, KALIMANTAN BARAT
}

\section{ROCK MASS EVALUATION OF EKO-REMAJA URANIUM EXPLORATION TUNNEL, KALAN, WEST KALIMANTAN}

\author{
Dhatu Kamajati*, Heri Syaeful, dan Mirna Berliana Garwan \\ Pusat Teknologi Bahan Galian Nuklir, Badan Tenaga Nuklir Nasional \\ Jl. Lebak Bulus Raya No. 09 Ps. Jumat, Jakarta 12440 \\ *E-mail: dhatukamajati@batan.go.id
}

Naskah diterima: 29 Oktober 2016, direvisi: 22 November 2016, disetujui: 25 November 2016

\begin{abstract}
ABSTRAK
Terowongan eksplorasi uranium Eko Remaja, Kalan, Kalimantan Barat merupakan salah satu sarana penelitian cebakan uranium yang sangat penting. Terowongan ini dibangun tahun 1980 dengan panjang 618 meter dan menembus Bukit Eko di kedua sisinya. Batuan di terowongan ini relatif kompak, tetapi memiliki zona lemah di beberapa bagiannya. Penyanggaan merupakan metode yang digunakan untuk menanggulangi keruntuhan tanah dan batuan yang terjadi pada zona lemah di terowongan. Pemasangan penyangga yang selama ini dilakukan berdasarkan pola keruntuhan yang terjadi pada saat pembukaan terowongan tanpa melalui studi khusus menyangkut karakterisasi massa batuan dan kebutuhan sistem penyangga. Penelitian ini dilakukan untuk mengevaluasi tingkat keselamatan terowongan Eko-Remaja dan kesesuaian lokasi penyangga. Evaluasi dilakukan dengan membandingkan karakteristik massa batuan menggunakan metode Rock Mass Rating (RMR) antara lokasi penyangga batuan terpasang dan lokasi penyangga batuan tidak terpasang. Berdasarkan hasil analisis, nilai RMR pada lokasi terpasang penyangga diklasifikasikan ke dalam kelas IV atau batuan buruk. Sementara itu, di lokasi tidak terpasang penyangga batuan diklasifikasikan ke dalam kelas II atau batuan baik. Berdasarkan korelasi antara hasil perhitungan RMR dengan roof span terowongan Eko-Remaja disimpulkan bahwa posisi penyanggaan terowongan yang diwakili oleh lokasi pengamatan pada kedalaman 38 m, 73 m, dan 165 m sudah sesuai dengan sistem karakterisasi massa batuan menggunakan metode RMR.
\end{abstract}

Kata kunci: evaluasi, massa, batuan, terowongan, penyanggaan, eksplorasi, uranium

\begin{abstract}
Eko-Remaja uranium exploration tunnel, Kalan, West Kalimantan is one of the important facilities for uranium deposit research. The tunnel was built in 1980 with a length of 618 meters penetrating Eko Hill on both sides. The rock inside the tunnel is relatively compact, but it has weak zones in some area. Ground supporting is a method used to overcome the soil and rock collapses which occurred in the tunnel weak zones. Installation of ground supporting system throughout the recent time based on the soil collapse pattern, which occurred when the tunnel opened without any specific study related to rock mass characterization and the requirement of ground support system. This research conducted to evaluate the safety level of Eko-Remaja tunnel and the suitability of ground support location. The evaluation performed by comparing the rock mass characteristics using Rock Mass Rating (RMR) method between the installed rock support and uninstalled rock support locations. Based on the analysis result, RMR value on the installed ground support is classified as class IV or poor rock. Meanwhile, on uninstalled location, the rock is classified as class II or fair rock. Based on the correlation between RMR calculation result and Eko-Remaja tunnel roof span, it is concluded that tunnel ground supports position which are represented by observation location on $38 \mathrm{~m}, 73 \mathrm{~m}$, and $165 \mathrm{~m}$ depth are suitable with rock mass characterization system using RMR method.
\end{abstract}

Keywords: evaluation, mass, rock, tunnel, ground supporting, exploration, uranium 


\section{PENDAHULUAN}

Terowongan eksplorasi uranium Eko Remaja, Kalan, Kalimantan Barat merupakan salah satu sektor potensial dan sarana penelitian cebakan uranium. Secara administratif, Kalan termasuk ke dalam Desa Kalan, Kecamatan Ella Ilir, Kabupaten Melawi (Gambar 1). Terowongan ini dibangun mulai tahun 1980, berada pada level 450 meter di atas permukaan air laut dengan arah $\mathrm{N} \mathrm{50^{ \circ }}$ E sepanjang 618 meter dan menembus dua sisi Bukit Eko. Terowongan ini memiliki zona batuan lapuk atau lemah, yaitu meter 0-38, meter 308-350, dan meter 535-618 [1].

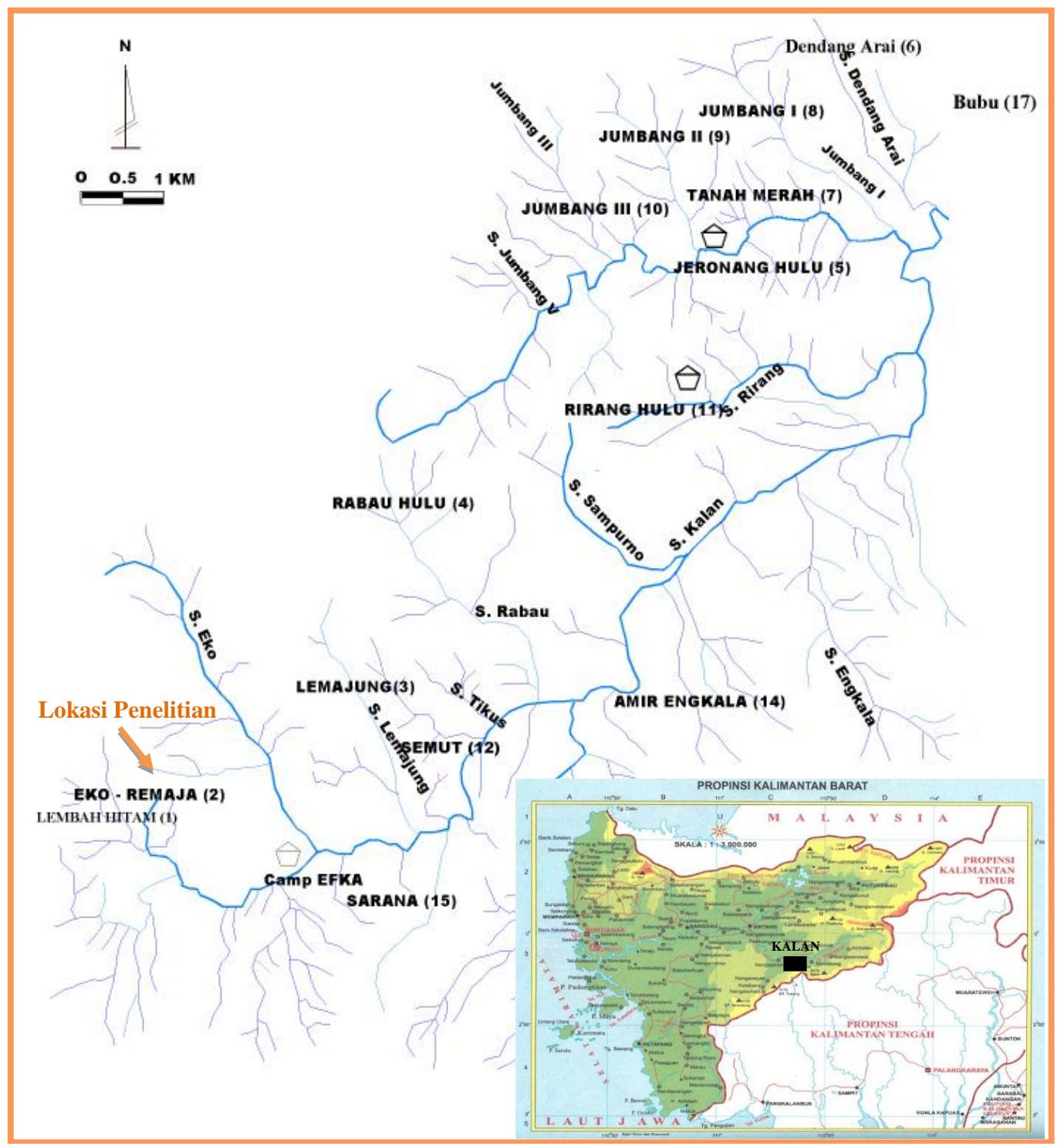

Gambar 1. Lokasi penelitian di terowongan Eko-Remaja, Kalan yang secara administrasi termasuk ke dalam Kabupaten Melawi, Kalimantan Barat.

Penyanggaan merupakan salah satu metode yang digunakan untuk menanggulangi keruntuhan tanah dan batuan yang terjadi pada terowongan. Penyangga yang terpasang pada terowongan adalah penyangga kayu dengan jenis kayu Keladan sebagai material penyangganya sedangkan pada zona tanah dan batuan yang sangat lapuk di bagian muka terowongan penyanggaan kayu Keladan ditambah dengan papan agar material tanah 
dan pecahan batuan tidak jatuh (Gambar 2). Pemasangan sistem penyangga tersebut didasarkan pada pola keruntuhan yang terjadi pada saat pembukaan terowongan tanpa melalui studi khusus menyangkut karakteristik massa batuan dan kebutuhan sistem penyangga.

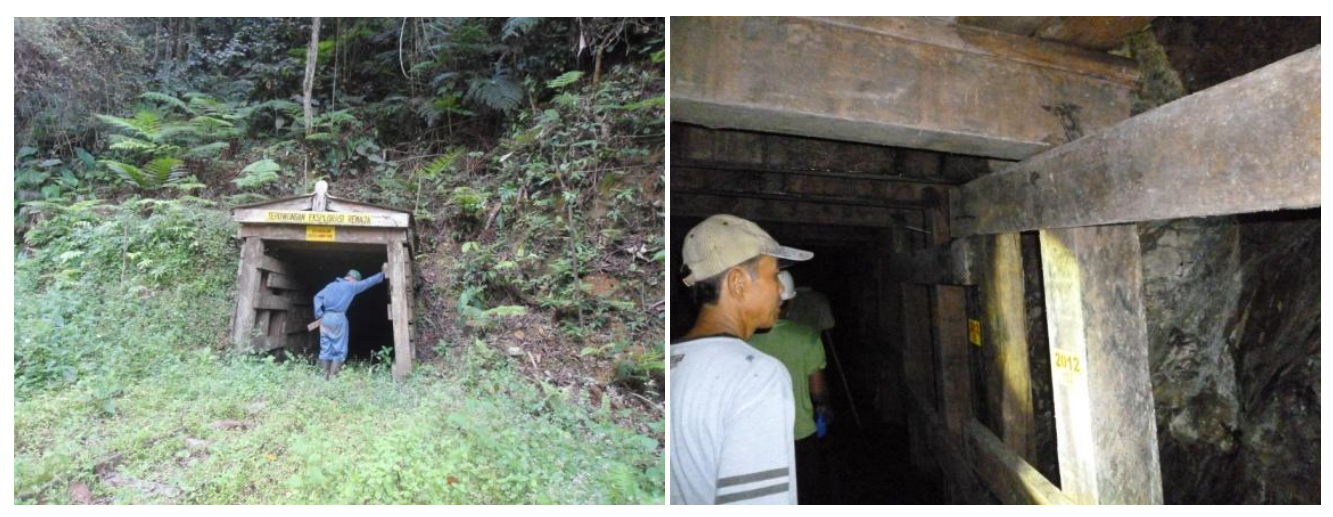

Gambar 2. Mulut terowongan Eko-Remaja (kiri) dan sistem penyangga terowongan menggunakan kayu Keladan (kanan).

Terowongan Eko-Remaja yang merupakan sarana penelitian cabakan uranium harus aman bagi manusia yang bekerja di dalamnya. Oleh karena itu analisis penilaian massa batuan diperlukan dalam rangka menganalisis keselamatan terowongan Eko-Remaja dan kesesuaian sistem penyangga. Penilaian massa batuan diperlukan dalam suatu rancangan terowongan pada tambang bawah tanah. Perhitungan sifat-sifat teknis dari massa batuan menjadi hal yang penting untuk diperhatikan [2]. Metode penilaian massa batuan telah diterapkan secara luas untuk aplikasi yang beragam seperti terowongan, pondasi, penambangan, dan manajemen geologi bencana. Tingkat akurasi dalam prediksi, evaluasi, dan interpretasi kualitas massa batuan merupakan kunci dari pelaksanaan lapangan [3]. Metode penilaian massa batuan melibatkan proses analisis kuat tekan batuan intact dan sifat diskontinuitas yang secara signifikan mempengaruhi estimasi perilaku teknik dari suatu massa batuan [4]. Metode penilaian massa batuan telah banyak dikembangkan dan digunakan dalam kegiatan rekayasa teknik, antara lain: prediksi kecepatan penetrasi pemboran pada terowongan [5], analisis perilaku massa batuan setelah penutupan terowongan [6], analisis pengaruh air pada bidang diskontinuitas terhadap stabilitas massa batuan [7], pemodelan aliran airtanah pada batuan terfrakturasi di terowongan [8], dan kestabilan lereng pada potongan massa batuan di jalan raya [4].

Salah satu sistem klasifikasi massa batuan yang umum digunakan saat ini adalah klasifikasi geomekanika atau dikenal juga dengan sistem Rock Mass Rating (RMR). Sistem ini dikembangkan untuk desain ekskavasi batuan yang memerlukan evaluasi sifat mekanika dari material batuan [2]. Tujuan dilakukannya penelitian ini adalah untuk mengevaluasi potensi keruntuhan dan posisi penyanggaan berdasarkan penilaian massa batuan dengan metode RMR pada terowongan utama Eko-Remaja. 


\section{TEORI}

Klasifikasi massa batuan adalah salah satu metode pendekatan yang dapat digunakan untuk membuat desain lubang bukaan bawah tanah. Nilai RMR merupakan hasil total penjumlahan dari pembobotan yang dilakukan untuk setiap parameternya. Setiap parameter RMR memiliki nilai pembobotan yang dibuat berdasarkan pengalaman dan database di berbagai lokasi tambang. Bobot dari semua parameter dijumlahkan untuk memperoleh bobot total massa batuan. Parameter-parameter yang digunakan adalah sebagai berikut :

1. Kuat Tekan Uniaksial (uniaxial), merupakan kekuatan batuan setelah memperoleh gaya dari satu arah. Akibat dari tekanan yang diberikan pada contoh batuan akan menunjukkan perilaku sebagai reaksi atas tegangan yang diberikan. Klasifikasi kuat tekan uniaksial diuraikan pada Tabel 1.

Tabel 1. Klasifikasi kekuatan batuan [2].

\begin{tabular}{lcc}
\hline \multicolumn{1}{c}{ Deskripsi } & $\begin{array}{c}\text { Kuat tekan uniaksial, } \\
(\mathbf{M p a})\end{array}$ & $\begin{array}{c}\text { Indeks kekuatan point-load, } \\
(\mathbf{M p a})\end{array}$ \\
\hline Sangat kuat & $>200$ & $>8$ \\
Kekuatan tinggi & $100-200$ & $4-8$ \\
Kekuatan menengah & $50-100$ & $2-4$ \\
Kekuatan rendah & $25-50$ & $1-2$ \\
Kekuatan sangat rendah & $<25$ & $<1$ \\
\hline
\end{tabular}

2. Rock Quality Designation (RQD), dihitung dari data frekuensi kekar pada permukaan batuan dengan persamaan: RQD $=100 \mathrm{e}^{-0.1 \lambda}(0.1 \lambda+1)$, dimana: $\lambda=$ rata-rata frekuensi kekar/meter [9].

3. Spasi Diskontinuitas. Kestabilan massa batuan bergantung pada adanya bidangbidang diskontinuitas. Secara lebih spesifik, bidang diskontinuitas juga memiliki sifat mekanis yang berhubungan dengan kondisi morfologi bidang diskontinuitas seperti bukaan dan kekasaran [7]. Kekar pada massa batuan cenderung akan memperburuk karakteristik mekanik massa batuan, yang bergantung pada frekuensi, jarak, dan orientasi (jurus dan kemiringan) kekar. Jarak antar kekar adalah jarak tegak lurus antara dua kekar berurutan sepanjang garis pengukuran kekar.

4. Kondisi Bidang Diskontinuitas. Beberapa hal harus diamati untuk menentukan kondisi bidang diskontinuitas batuan, yaitu pemisahan, kemenerusan, tingkat pelapukan, kekasaran, dan material pengisi.

5. Kondisi Air Tanah. Pada terowongan perhitungan besaran masuknya air tanah dihitung dalam satuan liter per 10 meter dari penggalian. Sebagai alternatif, kondisi umum dapat dinyatakan dalam kering, lembab, basah, air menetes, dan air mengalir.

Gabungan data dari penilaian kekuatan material batuan, RQD, spasi diskontinuitas, kondisi bidang diskontinuitas, dan airtanah digabungkan dalam penilaian sistem RMR (Tabel 2). Hasil dari penjumlahan bobot masing-masing parameter RMR kemudian digunakan untuk menentukan kelas batuannya berdasarkan tabel klasifikasi massa batuan (Tabel 3). 
Tabel 2. Parameter sistem RMR [10].

\begin{tabular}{|c|c|c|c|c|c|c|c|c|c|}
\hline \multicolumn{3}{|c|}{ Parameter } & \multicolumn{7}{|c|}{ Rentang nilai } \\
\hline \multirow{2}{*}{1} & \multirow{2}{*}{$\begin{array}{l}\text { Kekuatan } \\
\text { dari } \\
\text { material } \\
\text { batuan } \\
\text { utuh }\end{array}$} & \multirow{2}{*}{$\begin{array}{l}\begin{array}{l}\text { Indeks } \\
\text { point-load }\end{array} \\
\begin{array}{l}\text { Kuat tekan } \\
\text { uniaksial }\end{array}\end{array}$} & \multirow{2}{*}{$\begin{array}{l}>10 \mathrm{MPa} \\
>250 \mathrm{MPa}\end{array}$} & \multirow{2}{*}{$\begin{array}{l}4-10 \mathrm{MPa} \\
100-250 \mathrm{MPa}\end{array}$} & \multirow{2}{*}{$\begin{array}{l}2-4 \mathrm{MPa} \\
50-100 \mathrm{MPa}\end{array}$} & \multirow{2}{*}{$\begin{array}{l}1-2 \mathrm{MPa} \\
25-50 \mathrm{MPa}\end{array}$} & \multicolumn{3}{|c|}{$\begin{array}{l}\text { Untuk nilai rendah digunakan } \\
\text { uji kuat tekan }\end{array}$} \\
\hline & & & & & & & $5-25 \mathrm{MPa}$ & $1-5 \mathrm{MPa}$ & $<1 \mathrm{Mpa}$ \\
\hline & Bobot & & 15 & 12 & 7 & 4 & 2 & 1 & 0 \\
\hline \multirow[t]{2}{*}{2} & \multicolumn{2}{|l|}{ RQD } & $90 \%-100 \%$ & $75 \%-90 \%$ & $50 \%-75 \%$ & $25 \%-50 \%$ & \multicolumn{3}{|l|}{$<25 \%$} \\
\hline & \multicolumn{2}{|l|}{ Bobot } & 20 & 17 & 13 & 8 & \multicolumn{3}{|l|}{3} \\
\hline \multirow[t]{2}{*}{3} & \multicolumn{2}{|c|}{ Spasi diskontinuitas } & $>2 \mathrm{~m}$ & $0,6-2 \mathrm{~m}$ & $200-600 \mathrm{~mm}$ & $60-200 \mathrm{~mm}$ & \multicolumn{3}{|l|}{$<60 \mathrm{~mm}$} \\
\hline & \multicolumn{2}{|l|}{ Bobot } & 20 & 15 & 10 & 8 & \multicolumn{3}{|l|}{5} \\
\hline \multirow[t]{2}{*}{4} & \multicolumn{2}{|c|}{$\begin{array}{l}\text { Kondisi bidang } \\
\text { diskontinuitas }\end{array}$} & $\begin{array}{l}\text { Permukaan } \\
\text { sangat kasar, } \\
\text { tidak menerus, } \\
\text { tidak ada } \\
\text { pemisah, } \\
\text { batuan tidak } \\
\text { lapuk }\end{array}$ & $\begin{array}{l}\text { Permukaan } \\
\text { agak kasar, } \\
\text { jarak pemisah } \\
<1 \mathrm{~mm} \text {, } \\
\text { batuan agak } \\
\text { lapuk }\end{array}$ & $\begin{array}{l}\text { Permukaan } \\
\text { agak kasar, } \\
\text { jarak pemisah } \\
<1 \mathrm{~mm} \text {, } \\
\text { batuan sangat } \\
\text { lapuk }\end{array}$ & $\begin{array}{l}\text { Permukaan } \\
\text { slickensided } \\
\text { atau jarak } \\
\text { pemisah } 1-5 \\
\text { mm }\end{array}$ & \multicolumn{3}{|c|}{ Jarak pemisah > $5 \mathrm{~mm}$} \\
\hline & \multicolumn{2}{|l|}{ Bobot } & 30 & 25 & 20 & 10 & \multicolumn{3}{|l|}{0} \\
\hline \multirow[t]{3}{*}{5} & \multirow[t]{3}{*}{ Air tanah } & $\begin{array}{l}\text { Aliran per } \\
10 \mathrm{~m} \\
\text { panjang } \\
\text { terowongan } \\
(1 / \mathrm{m})\end{array}$ & Tidak ada & $<10$ & $10-25$ & $25-125$ & \multicolumn{3}{|l|}{$>125$} \\
\hline & & $\begin{array}{l}\text { Tekanan air } \\
\text { pada kekar }\end{array}$ & 0 & $<0,1$ & $0,1-0,2$ & $0,2-0,5$ & \multicolumn{3}{|l|}{$>0,5$} \\
\hline & & $\begin{array}{l}\text { Kondisi } \\
\text { umum }\end{array}$ & Kering & Lembab & Basah & Menetes & \multicolumn{3}{|l|}{ Mengalir } \\
\hline & \multicolumn{2}{|l|}{ Bobot } & 15 & 10 & 7 & 4 & \multicolumn{3}{|l|}{0} \\
\hline
\end{tabular}

Tabel 3. Klasifikasi Massa Batuan [10].

\begin{tabular}{lcl}
\hline \multicolumn{1}{c}{ Bobot } & Nomor Kelas & \multicolumn{1}{c}{ Deskripsi } \\
\hline $100-81$ & I & Batuan sangat baik \\
$80-61$ & II & Batuan baik \\
$60-41$ & III & Batuan sedang \\
$40-21$ & IV & Batuan buruk \\
$<21$ & V & Batuan sangat buruk \\
\hline
\end{tabular}

Kriteria analisis kestabilan terowongan dapat dinyatakan dalam bentuk grafik hubungan antara RMR terhadap span design untuk mengetahui nilai stand-up time dan mengetahui kondisi kestabilan terowongan (Gambar 2). Parameter stand-up time dalam mekanika batuan dan desain terowongan mempengaruhi keputusan dalam pemilihan metode ekskavasi, siklus ekskavasi dan metode perkuatan batuan, dan waktu untuk memasang penyangga batuan [11].

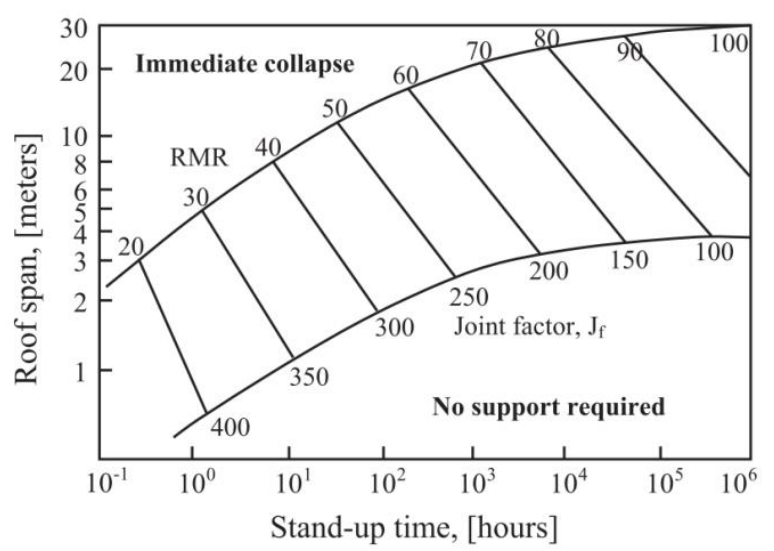

Gambar 2. Grafik hubungan roof span dengan stand-up time menurut RMR System [11]. 


\section{METODOLOGI}

Evaluasi untuk kondisi batuan dilakukan berdasarkan klasifikasi massa batuan dengan menggunakan metode RMR. Zona penyanggaan pada terowongan terbagi dalam tiga zona, yaitu zona kedalaman 0-63 m, zona 277-355 m, dan zona 535-618 m dari portal terowongan Eko-Remaja [12]. Penelitian menggunakan data hasil pengamatan langsung pada dinding terowongan utama, yaitu pada Lokasi Pengamatan 1 (LP1) di meter ke-38, LP2 pada meter ke-73, dan LP3 pada meter ke-165. LP1 merupakan lokasi pengamatan dengan penyangga terpasang sedangkan LP2 dan LP3 merupakan lokasi tanpa penyangga sehingga dapat digunakan sebagai perbandingan penilaian massa batuan (Gambar 3).

Pengambilan data kuat tekan batuan didapatkan dari uji in-situ dengan menggunakan alat schmidt hammer. Alat ini banyak digunakan dalam teknik sipil untuk menentukan kekuatan permukaan beton. Selain itu, penggunaannya dalam mekanika batuan dan aplikasi pertambangan telah menjadi subyek banyak penelitian [13] Prinsip kerja alat ini, yaitu dengan mengkonversi nilai pantulan (rebound) yang dihasilkan dari gaya hantaman beban alat melalui grafik atau tabel yang berada pada alat [14].

Hasil dari perhitungan RMR ini kemudian akan digunakan dalam menentukan kelas batuan dan interpretasi stand-up time, termasuk evaluasi posisi zona penyanggaan dinding terowongan. Data untuk perhitungan RQD, spasi diskontinuitas, kondisi bidang diskontinuitas, dan air tanah didapatkan dengan melakukan pengamatan langsung pada dinding terowongan.

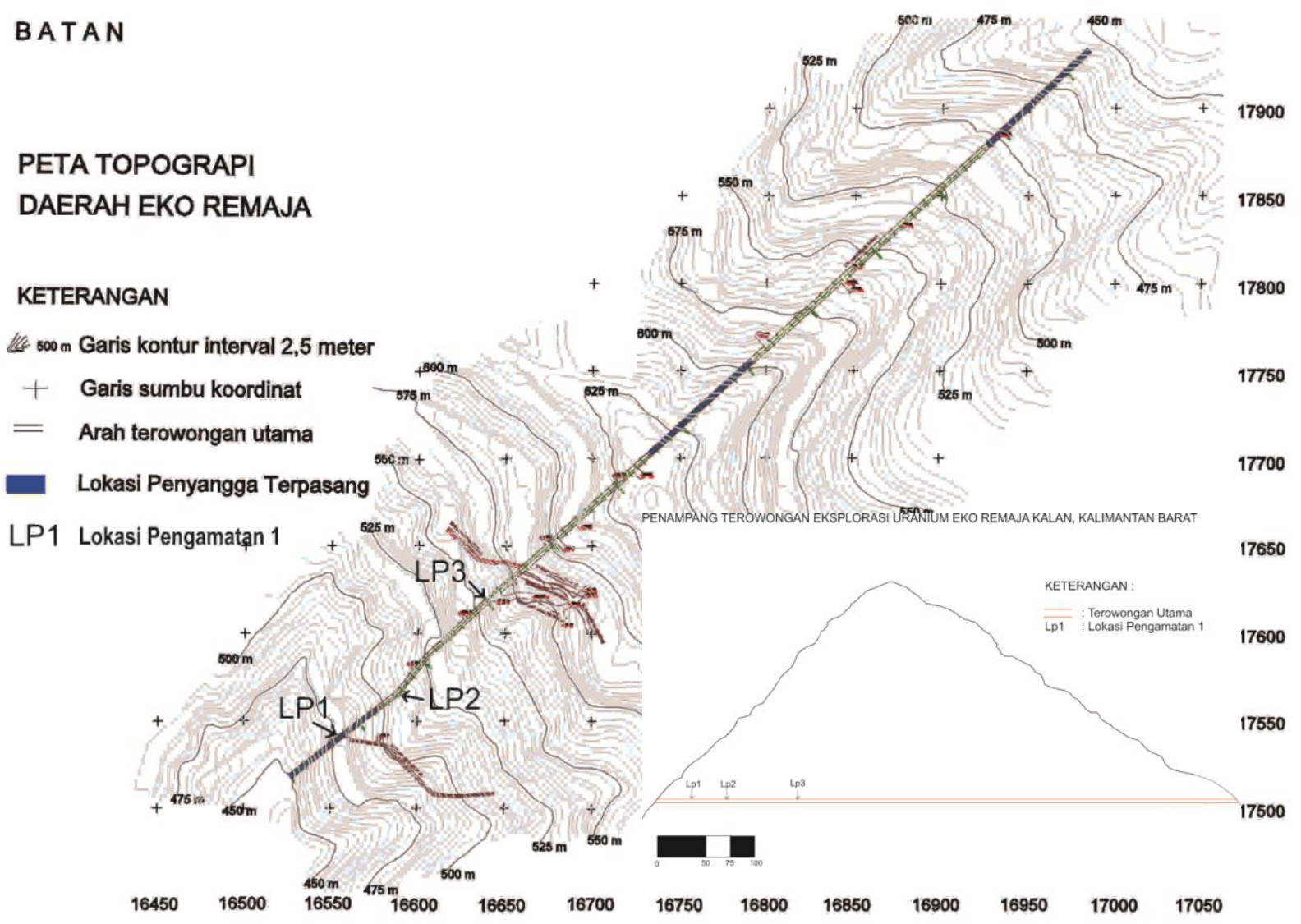

Gambar 3. Lokasi pengamatan pada terowongan Eko-Remaja. 


\section{HASIL DAN PEMBAHASAN}

Jenis batuan di dalam terowongan terdiri atas metaampelit, metapelit, dan metalanau. Secara umum, jurus dan kemiringan rata-rata litologi $\mathrm{N} 50^{\circ} \mathrm{E} / 50^{\circ}$, sekistositas $\mathrm{N} 50^{\circ}$ $\mathrm{E} / 70^{\circ}-80^{\circ}$, sedangkan bidang mineralisasinya bergantung pada litologi dan kontrol tektonik. Secara umum bidang mineralisasi tersebut mempunyai arah jurus berkisar $\mathrm{N} 70^{\circ}-88^{\circ}$ $\mathrm{E} / 80^{\circ}[15]$.

Pengambilan data kuat tekan batuan dilakukan dengan menggunakan alat schmidt hammer pada batuan di dinding terowongan. Pengambilan data sebanyak 15 kali pukulan pada masing-masing lokasi (Tabel 4).

Tabel 4. Data hasil pengambilan kuat tekan batuan dengan menggunakan alat Schmidt Hammer.

\begin{tabular}{ccc}
\hline Lokasi & $\begin{array}{c}\text { Nilai Kuat Tekan } \\
(\mathbf{R})\end{array}$ & $\begin{array}{c}\text { Nilai Rata-rata } \\
(\mathbf{R})\end{array}$ \\
\hline LP1 & $20-61$ & 34,7 \\
LP2 & $18-71$ & 46,9 \\
LP3 & $18-70$ & 41,3 \\
\hline
\end{tabular}
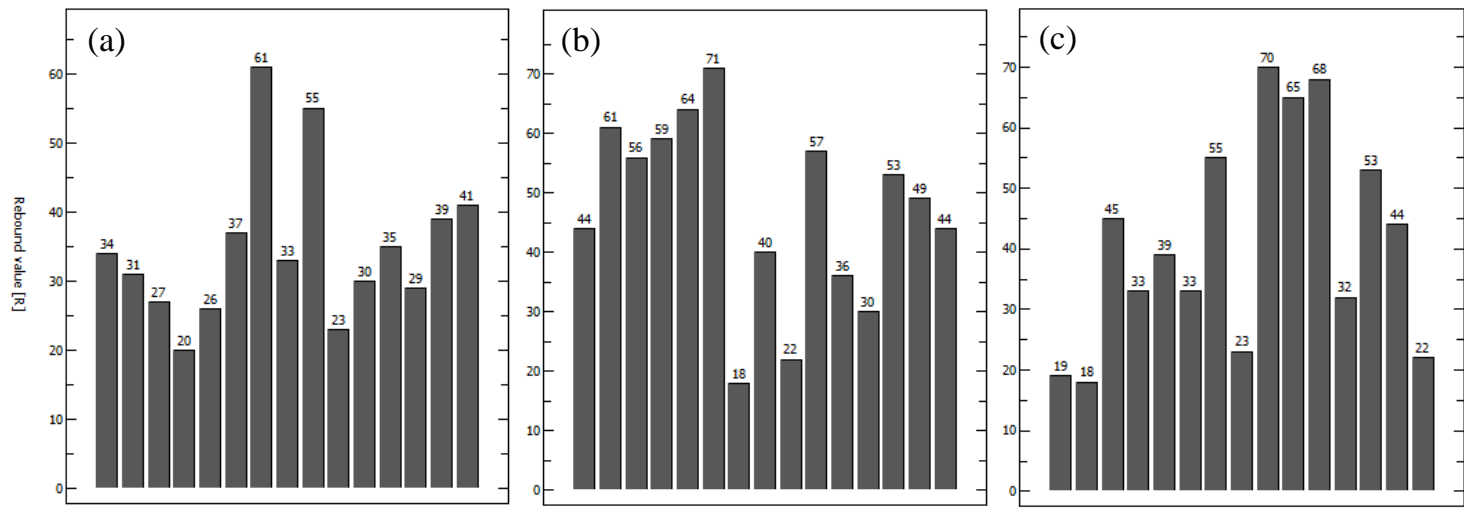

Gambar 4. Hasil pengukuran kuat tekan batuan menggunakan schmidt hammerpada (a) LP1, (b) LP2, dan (c) LP3.

Konversi hasil pengukuran menggunakan schmidt hammer menjadi nilai UCS dilakukan berdasarkan nilai konversi yang diusulkan oleh Yilmaz dan Sendir [16]. Berdasarkan hasil perhitungan didapatkan nilai UCS untuk LP1 sebesar $18 \mathrm{MPa}$, LP2 sebesar $36 \mathrm{MPa}$, dan LP3 sebesar $26 \mathrm{MPa}$ (Tabel 5).

Tabel 5. Konversi hasil pengukuran kekerasan batuan [16].

\begin{tabular}{ccc}
\hline Lokasi & $\begin{array}{c}\text { Rata-rata } \\
\text { (Rebound) }\end{array}$ & $\begin{array}{c}\text { Konversi UCS } \\
\text { (Mpa) }\end{array}$ \\
\hline LP1 & 34,7 & 18 \\
LP2 & 46,9 & 36 \\
LP3 & 41,3 & 26 \\
\hline
\end{tabular}

Hasil pengukuran menggunakan schmidt hammer tersebut tidak jauh berbeda dengan hasil pengukuran kuat tekan uniaksial pada batuan sejenis dari Sektor Lemajung, terutama pada batuan yang dekat dengan permukaan (tabel 6). Pada batuan Sektor Lemajung yang berjarak $3 \mathrm{~km}$ dari terowongan Eko-Remaja, nilai UCS hasil uji laboratorium inti bor batuan metalanau steril menunjukkan pola nilai UCS membesar berdasarkan kedalaman.

Tabel 6. Hasil pengukuran kuat tekan uniaksial pada batuan sejenis dari sektor Lemajung [17].

\begin{tabular}{lc}
\hline \multicolumn{1}{c}{ Lokasi } & $\begin{array}{c}\text { Nilai UCS } \\
\text { (MPa) }\end{array}$ \\
\hline Kedalaman 65 m & 38 \\
Kedalaman 132 m & 63 \\
Kedalaman 198 m & 77 \\
Kedalaman 265 m & 123 \\
Kedalaman 283 m & 136 \\
\hline
\end{tabular}


Bidang diskontinuitas di terowongan Eko-Remaja terbentuk akibat terjadinya dua jenis deformasi, yaitu deformasi plastic dan deformasi brittle. Deformasi plastic berhubungan dengan pembentukan urat-urat mineralisasi yang menarik dari segi sumberdaya sedangkan deformasi brittle yang terjadi pada fase terakhir tidak menghasilkan pergeseran karena bekerjanya sistem blok yang saling menghambat [15]. Berdasarkan pengamatan, bidang diskontinuitas yang ada adalah bidang sekistositas dan kekar-kekar yang berhubungan dengan sistem perlipatan $\mathrm{N} 70^{\circ} \mathrm{E} / 30^{\circ}$. Bidang diskontinuitas pada batuan metapelit pada umumnya mengisi bidang sekistositas sedangkan pada batuan metalanau berbentuk lebih masif yang mengikuti arah bukaan kekar.

Pada LP1 bidang diskontinuitas umumnya berupa kekar (joint) yang mempunyai dua arah umum, yaitu joint set 1

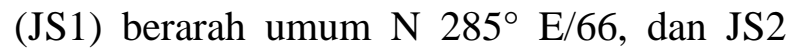
berarah umum $\mathrm{N} 135^{\circ} \mathrm{E} / 67^{\circ}$. Jarak antara kekar berkisar antara 5-9 cm. Pada LP2, bidang diskontinuitas JS1 mempunyai arah umum $\mathrm{N} 280^{\circ} \mathrm{E} / 66^{\circ}$ dan JS2 N $138^{\circ} \mathrm{E} / 67^{\circ}$, dengan jarak antar kekar 8-20 cm. Pada LP3, bidang diskontinuitas kekar JS1 berarah umum N $281^{\circ} \mathrm{E} / 67^{\circ}$ dan JS2 N $138^{\circ} \mathrm{E} / 67^{\circ}$, dengan jarak antar kekar 7-15 cm (Gambar 5). Secara umum bidang sekistositas (S1) di terowongan Eko-Remaja adalah $\mathrm{N} 280^{\circ} \mathrm{E} / 70^{\circ}$ (Gambar 6).
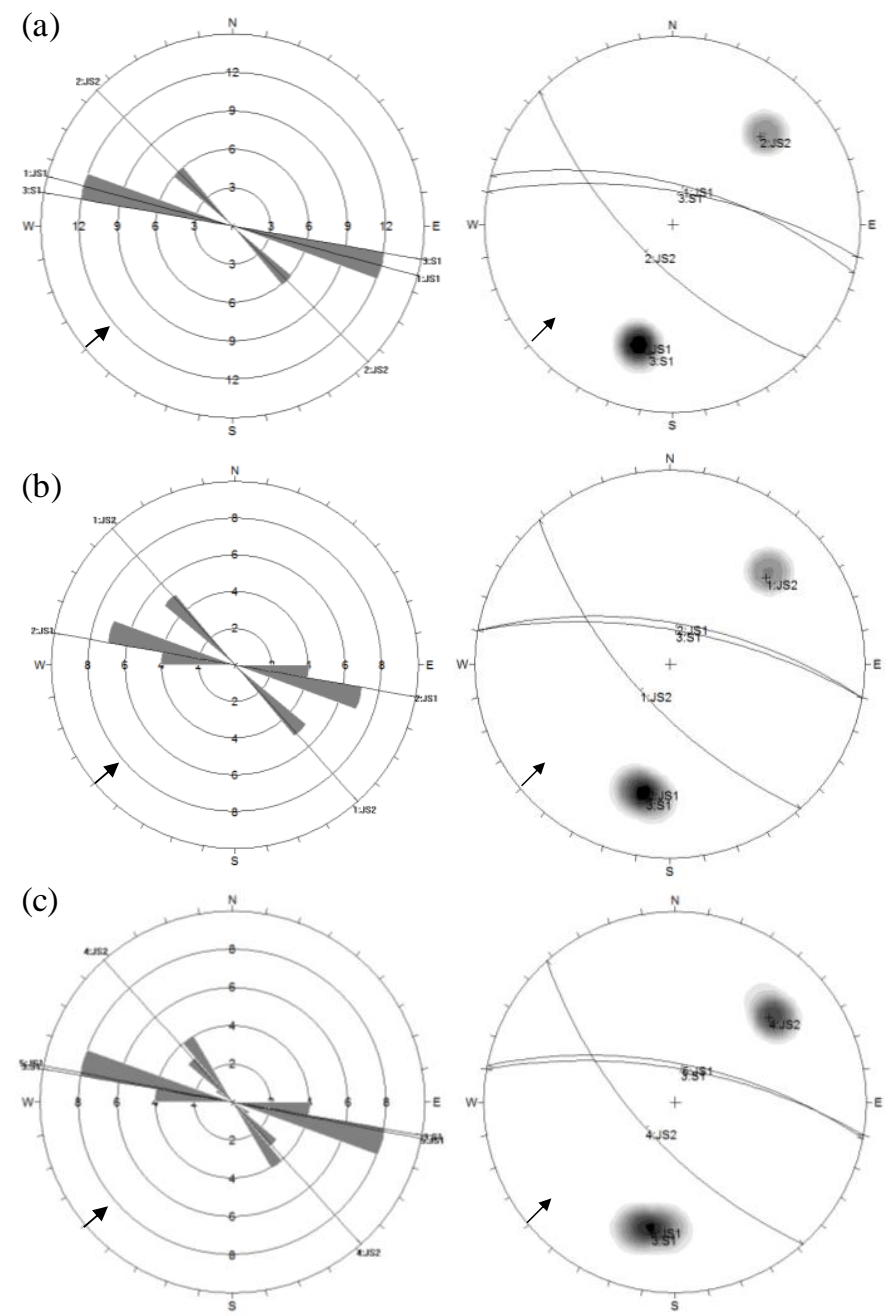

Gambar 5. Diagram kipas dan stereografi bidang diskontinuitas kekar dan sekistositas pada (a) LP1, (b) LP2, dan (c) LP3. Panah menunjukkan arah terowongan. 


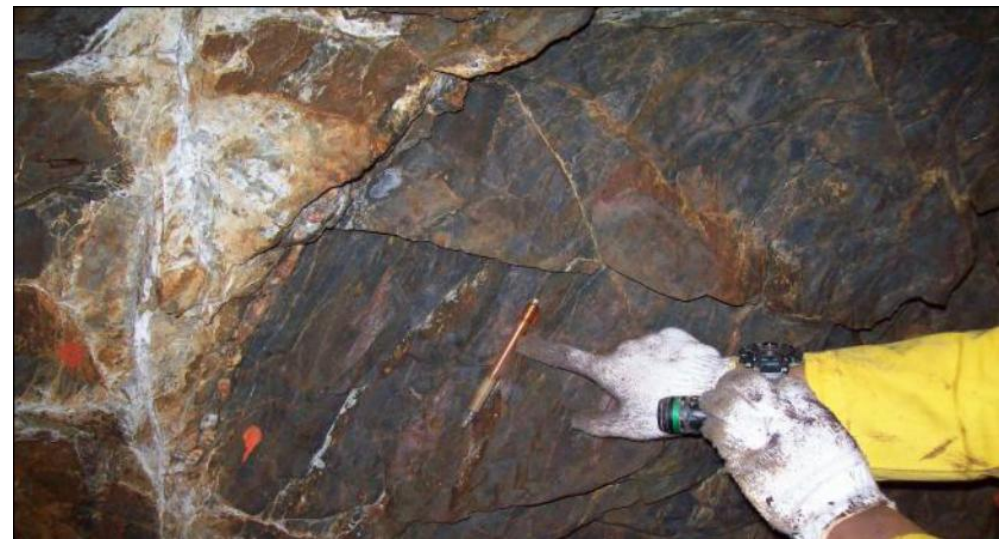

Gambar 6. Pola bidang diskontinuitas kekar dan sekistositas pada batuan metalanau di LP1.

Pengamatan dan perhitungan untuk pada LP1 secara umum menunjukkan mendapatkan nilai RQD, kondisi bidang permukaan halus dengan regangan antara 1-5 diskontinuitas, dan air tanah dilakukan pula mm yang diisi oleh kuarsa, sedangkan pada pada masing-masing lokasi pengamatan. LP2 dan LP3 kondisi permukaan bidang Berdasarkan hasil pengamatan dan diskontinuitas agak kasar dengan regangan 1perhitungan didapatkan nilai RQD untuk $5 \mathrm{~mm}$ berisi kuarsa. Kondisi air tanah pada masing-masing lokasi, yaitu LP1 $=84,4 \%$, LP1 termasuk dalam kategori basah, LP2 LP2 $=96,30 \%$, dan LP3=90,97\%. Kondisi kategori kering dan LP3 kategori lembab bidang diskontinuitas dari hasil pengamatan (Gambar 7).

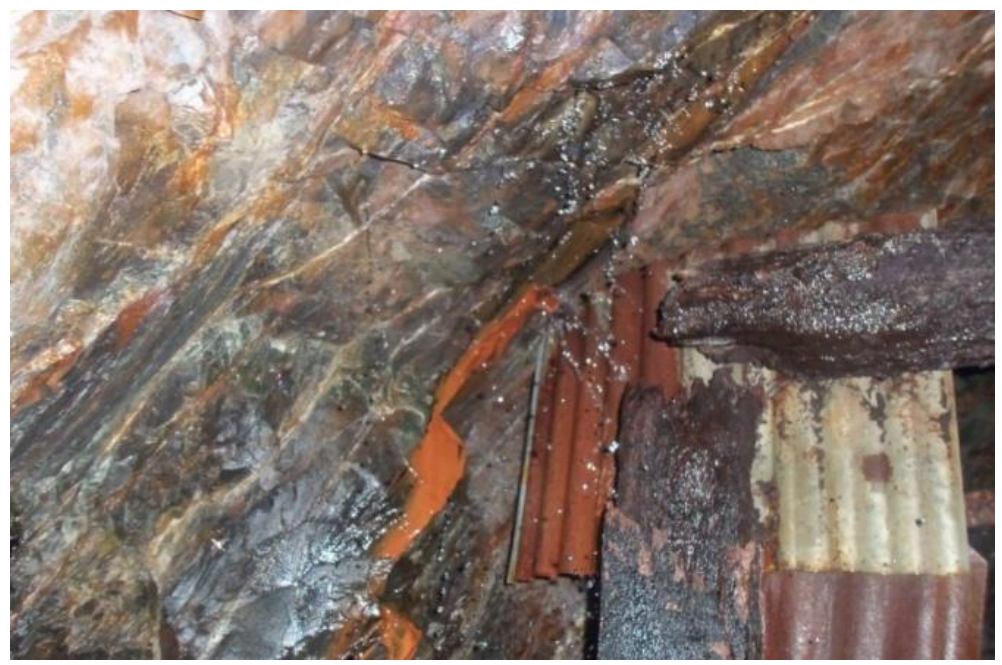

Gambar 7. Aliran airtanah pada rekahan di LP1.

Berdasarkan hasil analisis dari masingmasing parameter maka didapatkan nilai RMR masing-masing lokasi, yaitu: LP1 sebesar 39 (kelas IV atau batuan buruk), LP2 sebesar 67 (kelas II atau batuan baik), dan LP3 sebesar 62 (kelas II atau batuan baik). Perhitungan orientasi bidang diskontinuitas terhadap arah terowongan untuk menilai efek bidang diskontinuitas menghasilkan data arah terowongan tegak lurus dengan dominasi arah fraktur JS1 dan sekistositas dengan besaran sudut antara 50-60 (lihat Gambar 5). Oleh sebab itu, dapat disimpulkan bahwa arah bidang diskontinuitas sangat sesuai (very 
favourable) terhadap arah terowongan, sehingga tidak dilakukan pengurangan nilai RMR (Tabel 7) [2].

Korelasi data RMR dengan kondisi roof span terowongan Eko-Remaja bertujuan untuk mendapatkan data kesesuaian kondisi penyanggaan terowongan saat ini dengan data hasil penilaian massa batuan. Terowongan Eko-Remaja memiliki lebar rata-rata 2,4 meter sehingga hasil analisis hubungan antara RMR dengan roof span dapat disimpulkan bahwa kondisi batuan pada LP1 berada pada zona batuan yang membutuhkan penyangga, sedangkan pada LP2 dan LP3 tidak membutuhkan penyangga (Gambar 8). Hasil korelasi tersebut menunjukkan posisi penyanggaan pada terowongan yang diwakili oleh lokasi pengamatan LP1, LP2, dan LP3 pada kedalaman $38 \mathrm{~m}, 73 \mathrm{~m}$, dan $165 \mathrm{~m}$ sudah sesuai dengan sistem penilaian massa batuan menggunakan metode RMR.

Tabel 7. Hasil perhitungan RMR.

\begin{tabular}{|c|c|c|c|c|c|c|c|c|c|c|c|c|}
\hline \multirow{2}{*}{\multicolumn{2}{|c|}{$\begin{array}{c}\text { Lokasi } \\
\text { Pengamatan }\end{array}$}} & \multicolumn{2}{|c|}{$\begin{array}{c}\text { Kekuatan } \\
\text { contoh batuan }\end{array}$} & \multicolumn{2}{|c|}{ RQD } & \multicolumn{2}{|c|}{$\begin{array}{c}\text { Jarak } \\
\text { Diskontinuitas }\end{array}$} & \multicolumn{2}{|c|}{$\begin{array}{c}\text { Kondisi } \\
\text { Diskontinuitas }\end{array}$} & \multicolumn{2}{|c|}{ Airtanah } & \multirow{2}{*}{ RMR } \\
\hline & & $\begin{array}{l}\text { UCS( } \\
\text { Mpa) }\end{array}$ & Rating & $\%$ & Rating & $\begin{array}{c}\text { Jarak } \\
(\mathbf{c m})\end{array}$ & Rating & Uraian & Rating & $\begin{array}{c}\text { Kondisi } \\
\text { Umum }\end{array}$ & Rating & \\
\hline LP1 & $(38 \mathrm{~m})$ & 18 & 2 & 84,4 & 17 & $5-9$ & 3 & Halus & 10 & Basah & 7 & 39 \\
\hline LP2 & $(73 \mathrm{~m})$ & 36 & 4 & 96,3 & 20 & $8-20$ & 8 & $\begin{array}{l}\text { Agak } \\
\text { kasar }\end{array}$ & 20 & Kering & 15 & 67 \\
\hline LP3 & $(165 \mathrm{~m})$ & 26 & 4 & 91,0 & 20 & $7-13$ & 8 & $\begin{array}{l}\text { Agak } \\
\text { kasar }\end{array}$ & 20 & Lembab & 10 & 62 \\
\hline
\end{tabular}

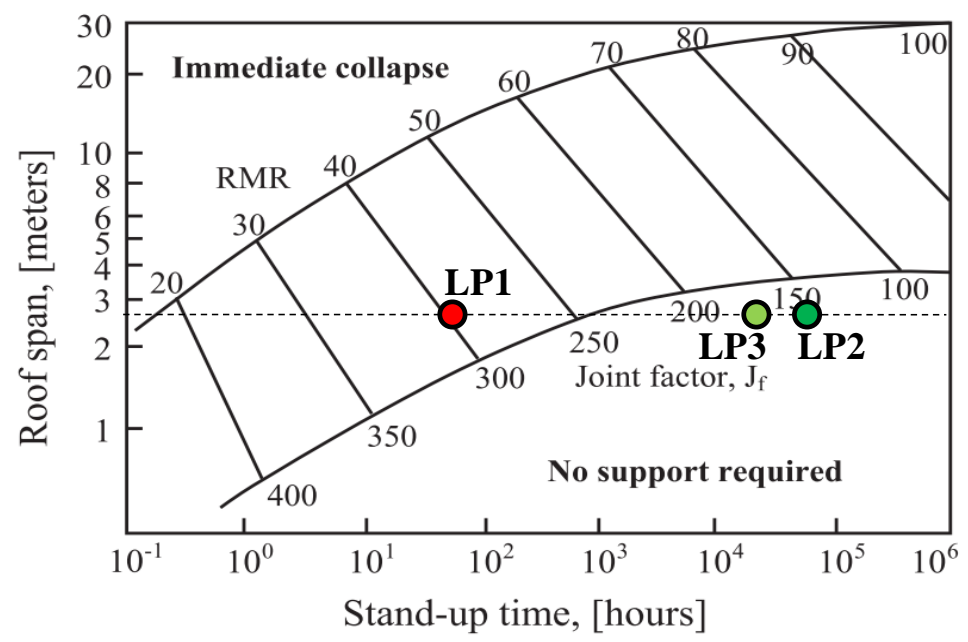

Gambar 8. Hasil analisis hubungan antara RMR dengan roof span pada masing-masing lokasi. 


\section{KESIMPULAN}

Jenis batuan di dalam terowongan terdiri atas metaampelit, metapelit dan metalanau. Kuat tekan uniaksial batuan berdasarkan pengukuran in-situ didapatkan nilai UCS antara $18 \mathrm{MPa}$ sampai $36 \mathrm{MPa}$. Bidang diskontinuitas berupa kekar mempunyai dua arah umum, yaitu $\mathrm{N} 280^{\circ}-285^{\circ} \mathrm{E}$ dengan dip antara $64^{\circ}-71^{\circ}$, dan bidang sekistositas (S1) $\mathrm{N} 280^{\circ} \mathrm{E} / 70^{\circ}$. Kondisi bidang diskontinuitas merupakan permukaan halus sampai agak kasar dengan regangan antara 1-5 mm yang diisi oleh kuarsa, nilai RQD berkisar antara 84,4\%-96,3\%. Airtanah dalam kategori basah sampai kering.

Analisis dari masing-masing parameter menghasilkan nilai RMR LP1 termasuk dalam kelas IV atau batuan buruk sedangkan LP2 dan LP3 termasuk dalam kategori batuan baik. Korelasi hasil perhitungan RMR dengan kondisi roof span terowongan Eko-Remaja disimpulkan bahwa kondisi batuan pada LP1 berada pada zona batuan yang membutuhkan penyangga sedangkan pada meter LP2 dan LP3 tidak membutuhkan penyangga. Hasil korelasi tersebut menunjukkan posisi penyanggaan pada terowongan yang diwakili oleh lokasi pengamatan LP1, LP2, dan LP3 pada kedalaman $38 \mathrm{~m}, 73 \mathrm{~m}$, dan $165 \mathrm{~m}$ sudah sesuai dengan sistem penilaian massa batuan menggunakan metode RMR.

\section{DAFTAR PUSTAKA}

[1] A. Zaenal, "Beton Cetak Bertulang sebagai Alternatif Pengganti Kayu Penyangga di Terowongan Eksplorasi U Eko Remaja Kal-Bar," Prosiding Seminar Geologi Nuklir dan Sumberdaya Tambang, 2006.

[2] Z. T. Bieniawski, Engineering Rock Mass Classification: A Complete Manual for Engineers and Geologists in Mining, Civil, and Petroleum Engineering. New York: John Wiley \& Sons, Inc., 1989.
[3] F. Ferrari, T. Apuani, and G. P. Giani, "Rock Mass Rating Spatial Estimation by Geostatistical Analysis," Int. J. Rock Mech. Min. Sci., vol. 70, pp. 162-176, 2014.

[4] S. S. D. P. Kanungo and S. Kumar, "Rock Mass Classification and Slope Stability Assessment of Road Cut Slopes in Garhwal Himalaya, India," 2012.

[5] A. Benato and P. Oreste, "Prediction of Penetration Per Revolution in TBM Tunneling as A Function of Intact Rock and Rock Mass Characteristics," Int. J. Rock Mech. Min. Sci., vol. 74, pp. 119-127, 2015.

[6] C. Chen and Y. Liu, "A Methodology for Evaluation and Classification of Rock Mass Quality on Tunnel Engineering," vol. 22, pp. 377-387, 2007.

[7] S. Dochez, F. Laouafa, C. Franck, S. Guedon, M. Bost, and J. D. Amato, "Influence of Water on Rock Discontinuities and Stability of Rock Mass," Procedia Earth Planet. Sci., vol. 7, pp. 219-222, 2013.

[8] H. Farhadian, H. Katibeh, P. Huggenberger, and C. Butscher, "Optimum Model Extent for Numerical Simulation of Tunnel Inflow in Fractured Rock," Tunn. Undergr. Sp. Technol., vol. 60, pp. 21-29, 2016.

[9] L. Zhang, "Journal of Rock Mechanics and Geotechnical Engineering Determination and Applications of Rock Quality Designation (RQD)," vol. 8, pp. 389-397, 2016.

[10] A. Lowson, "Critical Assessment of RMR based Tunnel Design Practices: a Practical Engineer's Approach," in Rapid Excavation \& Tunneling Conf., 2013.

[11] V. Nguyen and Q. Nguyen, "Analytical Solution for Estimating The Stand-Up Time of the Rock Mass Surrounding Tunnel," Tunn. Undergr. Sp. Technol. Inc. Trenchless Technol. Res., vol. 47, pp. 10-15, 2015.

[12] S. R. Rahutomo, "Evaluasi Penyanggaan pada Terowongan Eksplorasi Tambang Uranium EkoRemaja, Pusat Pengembangan Geologi NuklirBATAN, Kalimantan Barat," Skripsi UPN "Veteran" Yogyakarta, 2013.

[13] N. Bilgin, H. Copur, and C. Balci, "Use of Schmidt Hammer with Special Reference to Strength Reduction Factor Related to Cleat Presence in A Coal Mine," Int. J. Rock Mech. Min. Sci., vol. 84, pp. 25-33, 2016. 
[14] R. Arwanto, "Respon Kuat Tekan Hammer Test dengan Compression Test pada Beton Normal dan Beton Paska Bakar," Media Komun. Tek. Sipil, vol. 14, no. 1, pp. 85-94, 2006.

[15] H. S. Karyono, “Analisis Kontrol Tektonik pada Vein Mineralisasi di Bukit Eko, Kalan, Kalimantan Barat," in Prosiding Pertemuan Ilmiah Tahunan ke-2 IAGI, 1991, pp. 115-128.
[16] I. Yilmaz and H. Sendir, "Correlation of Schmidt Hardness with Unconfined Compressive Strength and Young's Modulus in Gypsum from Sivas (Turkey)," Eng. Geol., vol. 66, no. 3-4, pp. 211219, 2002.

[17] H. Syaeful, "Analisis Karakteristik Massa Batuan di Sektor Lemajung, Kalan, Kalimantan Barat," Eksplorium, vol. 36, no. 1, pp. 17-30, 2015. 